\title{
Special Acknowledgments
}

The two excavation seasons at Capo Alfiere in 1987 and 1990, and the study season in 1991, were, as all of ICA's projects in its first quarter century of existence in southern Italy, made possible by generous contributions from a number of loyal supporters. Special mention should be made of the three-year grants from the Brown Foundation of Houston and Maconda Brown O'Connor. To all, listed below, we owe a deep debt of gratitude.

The book itself would never have been conceived, much less produced in its current form, were it not for the constant and inspiring initiative of the Packard
Humanities Institute. PHI has provided funding not only for the additional research necessary to turn a dissertation and related specialist studies into a coherent presentation of the site, but also for the talented staff who prepared the material for publication at the ICA offices in Austin. This is a part of a much larger project, sponsored by $\mathrm{PHI}$, that makes possible the publication of archaeological research since 1974 at Metaponto and Croton in southern Italy, and Chersonesos in Crimea.

Joseph Coleman Carter Director, ICA

\section{Contributors}

Austin Community Foundation

Mr. and Mrs. Daniel Balz, Washington, D.C.

Mrs. Jane Bedichek, Scarsdale, NY

Dr. Leo* and Signora Bini, Rome

Mr. Stefano Bini, Rome

Mr. F. William Carr, Austin, TX

Mr.* and Mrs. Joseph Coleman Carter III, Versailles, KY

Mrs. Judy D. Coker, Austin, TX

Professor Marian Davis, ${ }^{*}$ Austin, TX

Professor* and Mrs. Ronald DeFord, Austin, TX

Mr. Gilbert Denman,* The Ewing Halsell

Foundation, San Antonio, TX

Professor Myron Dorfman, ${ }^{*}$ Austin, TX

Ms. Mary Patricia Dougherty, Santa Monica, CA

Mr. James R. Dougherty III, Austin, TX

Mr. Stephen T. Dougherty, Beeville, TX

Mr. Michael Guarino, Austin, TX

Mrs. Sandra Heinrichs, Austin, TX

Highland Resources, Houston, TX

I.B.M. (through Project Quest)

Mrs. May Dougherty King, ${ }^{*}$ Corpus Christi, TX

Mr. and Mrs. Daniel Kruger, San Antonio, TX

Mrs. Lois Ashton Larson, ${ }^{*}$ Elmhurst, IL
Mr. Warren Larson, Elmhurst, IL

Mr.* and Mrs. Frank McBee, Austin, TX

Mrs. Barbara McCluer, San Antonio, TX

Ms. Etelka McCluer, San Antonio, TX

Professor Benjamin Dean Meritt, ${ }^{*}$ Austin, TX

Professor Lucy Shoe Meritt, ${ }^{*}$ Austin, TX

Mr. Bert Henry Michelsen, ${ }^{*}$ Elmhurst, IL

Mr.* and Mrs.* George S. Nalle, Jr., Austin, TX

Maconda Brown O'Connor, Houston, TX

Ralph S. O'Connor, Houston, TX

Oryx Energy Company, Dallas, TX

The David and Lucille Packard Foundation, Palo Alto, CA

The Potts Sibley Foundation, Austin, TX

Mr. Philip Schaefer, Darien, CT

Ms. Johanna Smith, Oak Hill, TX

Texas Eastern, Houston, TX

Texas Tradewinds Travel, Austin, TX

Mr. Ben F. Vaughan, Jr., Corpus Christi, TX

Mr. and Mrs. Ben F. Vaughan III, Austin, TX

Ms. Genevieve Vaughn, Austin, TX

The Washington Post Matching Gifts Program

Mr. and Mrs. William Willis, Austin, TX

Col. Haskell Zipperman, ${ }^{*}$ San Antonio 